\title{
Optimalisasi Penggunaan Gipsum dan Batu Kapur pada Pembuatan Semen Putih
}

\author{
Ahmad Riyanto ${ }^{a, 1}$, Devi Yuliani ${ }^{\text {b,2 }}$, Laeli Rizki Amalia ${ }^{\text {b,3 }}$, Erna Astuti ${ }^{\text {b,4,* }}$ \\ ${ }^{a}$ Department of Quality Assurance, PT. Semen Indonesia (Persero) Tbk., Gresik \\ ${ }^{\text {b }}$ Program Studi Teknik Kimia, Fakultas Teknologi Industri, Universitas Ahmad Dahlan, Jl. Ring Road Selatan, Tamanan, Banguntapan, Bantul, Yogyakarta \\ 55166, Indonesia \\ ${ }^{1}$ ahmadriyanto.gmail.com; ${ }^{2}$ yulianidevi96@ gmail.com; ${ }^{3}$ leesrizkyoopsz@ gmail.com; ${ }^{4}$ erna.astuti@ che.uad.ac.id* \\ * corresponding author
}

ARTICLE INFO

\section{Article history}

Received November 16, 2019

Revised January 03, 2020

Accepted January 03, 2020

\section{Keywords}

Semen portland putih

Standar Nasional Indonesia

Komposisi

Loss on Ignition

$\mathrm{SO}_{3}$

Warna

\section{ABSTRACT}

White Portland cement is a fine, gray or white powder, which consists of a mixture of hydraulic cement materials consisting mainly of calcium silicate, aluminate, and aluminoferrite. The manufacture of white portland cement requires special raw material requirements and manufacturing processes, such as raw materials containing very low iron oxides and manganese oxides. Various tests were carried out to obtain white cement of good quality and meet Indonesian National Standards or Standar Nasional Indonesia (SNI). The tests included raw material testing (Lost on Ignition test, LOI) on various compositions and LOI test, \% $\mathrm{SO}_{3}$ test, and color test on white Portland cement. The results showed that the greater the $\% \mathrm{SO}_{3}$, the strength of white Portland cement will decrease and the greater the LOI, the white Portland cement will be easily damaged. So from the results of the study obtained a good raw material composition for white Portland cement is $89 \%$ white slag, $4 \%$ limestone, and $7 \%$ gypsum. All test results meet Indonesian National Standards or SNI.

This is an open access article under the CC-BY-SA license.

\section{Pendahuluan}

Semakin pesatnya perkembangan industri semen di Indonesia memunculkan beberapa tipe semen antara lain Ordinary Portland Cement (OPC), White Cement, dan Portland Composite Cement (PCC). Komposisi kimia semen meliputi $\mathrm{SiO}_{2}, \mathrm{Al}_{2} \mathrm{O}_{3}, \mathrm{Fe}_{2} \mathrm{O}_{3}, \mathrm{CaO}, \mathrm{MgO}, \mathrm{SO}_{3}, \mathrm{~K}_{2} \mathrm{O}, \mathrm{Ti}_{2} \mathrm{O}_{5}, \mathrm{P}_{2} \mathrm{O}_{5}$, dan $\mathrm{Cl}^{-}$[1]. Kandungan mineral semen putih meliputi $\mathrm{C}_{3} \mathrm{~S}, \mathrm{C}_{2} \mathrm{~S}, \mathrm{C}_{3} \mathrm{~A}$, dan $\mathrm{C}_{4} \mathrm{AF}$ [2]. Semen Portland meliputi 2 macam, yaitu semen dengan kadar gamping 6-20\% dan kadar 21-35\% sesuai standar UK nomor BS 7583: 1996 [3]. Semen portland adalah bubuk halus, berwarna abu-abu atau putih, yang terdiri dari campuran bahan semen hidrolik terutama terdiri dari kalsium silikat, aluminat, dan aluminoferrit. Semen portland putih memiliki kandungan besi dan mangan yang lebih rendah daripada semen portland abu-abu dan digunakan terutama untuk keperluan dekoratif. Kandungan oksida besi dan oksida magnesia dalam semen portland putih sangat rendah yaitu dibawah $1 \%[4,5]$. Semen portland putih dihasilkan dengan cara menggiling terak semen portland putih yang terutama terdiri atas kalsium, silikat, giling bersama-sama dengan bahan tambahan berupa satu atau lebih bentuk kristal senyawa kalsium sulfat. Kandungan senyawa yang terdapat dalam semen putih adalah Kalsium Oksida $(\mathrm{CaO})$, Besi Oksida $\left(\mathrm{Fe}_{2} \mathrm{O}_{3}\right)$, Silika Oksida $\left(\mathrm{SiO}_{2}\right)$, Aluminium Oksida $\left(\mathrm{Al}_{2} \mathrm{O}_{3}\right)$, dan Magnesium Oksida (MgO) [6].

Produk semen portland putih memiliki persyaratan tertentu untuk dipasarkan. Untuk mendapatkan semen putih dengan kualitas yang baik diberlakukan proporsi perbandingan antara terak putih, batu kapur, dan gypsum dengan melakukan pengujian produk secara fisika dan kimia. 
Setiap negara memiliki standar berbeda untuk menyatakan spesifikasi semen portland putih. Standar yang berlaku di India adalah IS 8042: 1989 yang diamandemen no. 5 April 2009 [7], sedangkan standar yang digunakan di Indonesia adalah SNI 15-0129-2004, meliputi sifat kimia dan sifat fisika semen portland putih [8]. Standar sifat kimia tertera pada Tabel 1.

Tabel 1. Syarat Kimia Semen Portland Putih

\begin{tabular}{ccc}
\hline Jenis Uji & Satuan & Persyaratan \\
\hline $\mathrm{MgO}$ & $\%$ & Maks. 5,0 \\
$\mathrm{SO}_{3}$ & $\%$ & Maks. 3,5 \\
$\mathrm{Fe}_{2} \mathrm{O}_{3}$ & $\%$ & Maks.0,4 \\
Hilang pijar (LOI) & $\%$ & Maks.5,0 \\
Bagian tak larut & $\%$ & Maks. 3,0 \\
\hline
\end{tabular}

Menurut standar Eropa EN 196-2:2013, bagian tak larut dinyatakan dengan metode $\mathrm{Na}_{2} \mathrm{CO}_{3}$ [1] . Salah satu syarat kimia semen portland putih yang tercantum di Tabel 1 adalah Loss On Ignition (LOI). Syarat kimia semen Portland putih tertera pada Tabel 2.

Tabel 2. Syarat Fisika Semen Portland Putih

\begin{tabular}{ccc}
\hline Uraian & Satuan & Persyaratan \\
\hline $\begin{array}{c}\text { Kehalusan dengan alat blaine } \\
\text { Waktu pengikat dengan alat vicat } \\
\text { - pengikatan awal }\end{array}$ & $\mathrm{m}^{2} / \mathrm{kg}$ & Min. 280 \\
$\begin{array}{c}\text { - pengikatan akhir } \\
\text { Kekekalan dengan autoclave } \\
\text { - pemuaian }\end{array}$ & $\begin{array}{c}\text { Menit } \\
\text { menit }\end{array}$ & $\begin{array}{c}\text { Min. } 45 \\
\text { Maks. } 375\end{array}$ \\
$\begin{array}{c}\text { Pengikatan semu } \\
\text {-penetrasi akhir }\end{array}$ & $\%$ & Maks 0,8 \\
$\begin{array}{c}\text { Derajat warna putih (whiteness) } \\
\text { - alat hunter lab }\end{array}$ & $\%$ & Min. 50 \\
- alat kett meter & $\%$ & Min. 90 \\
Kuat tekan: & $\%$ & Min. 80 \\
3 hari & & \\
7 hari & $\mathrm{kg} / \mathrm{cm}^{3}$ & Min. 180 \\
28 hari & $\mathrm{kg} / \mathrm{cm}^{3}$ & Min. 250 \\
$\mathrm{kg} / \mathrm{cm}^{3}$ & Min. 350 \\
\hline & &
\end{tabular}

Penelitian ini bertujuan mengetahui kondisi optimal penggunaan gypsum dan batu kapur pada semen putih di PT Semen Indonesia. Kondisi optimum diperoleh dari pengujian secara kimia yaitu uji LOI dan $\% \mathrm{SO}_{3}$ serta uji fisika dengan pengujian warna semen. Hasil uji dibandingkan dengan standar nasional produk semen portland putih di Indonesia.

\section{Metode Penelitian}

Bahan penyusun semen putih yang digunakan dalam penelitian ini adalah: gypsum, batu kapur, dan terak putih dari PT Semen Indonesia. Dalam penelitian dilakukan Uji Kimia Bahan Baku, Pembuatan Semen Portland Putih, Pengujian Kimia Semen Portland Putih yaitu uji LOI dan uji $\mathrm{SO}_{3}$, serta uji fisika berupa uji warna.

Uji hilang pijar dilakukan dengan memijarkan cawan porselin berisi sampel sebanyak 1 gram dalam tanur bersuhu $550{ }^{\circ} \mathrm{C}$ dan bersuhu $950{ }^{\circ} \mathrm{C}$ selama 30 menit. Kemudian cawan porselin berisi sampel tersebut didinginkan dalam desikator dan ditimbang sampai suhunya konstan dan dihitung LOI nya. Uji $\mathrm{SO}_{3}$ dilakukan dengan menggunakan XRF, sedangkan uji warna dilakukan dengan alat Kett Meter. Pengujian dilakukan dengan menumpuk sejumlah semen kering dengan rapi ke dalam cetakan berbentuk cincin dengan diameter $30 \mathrm{~mm}$ dan tinggi $3 \mathrm{~mm}$ (atau dengan menggunakan cetakan lain yang disediakan oleh alat kett meter) yang ditempatkan di atas suatu pelat kaca bersih. Lalu tekan perlahan-lahan dengan menggunakan pelat kaca yang lain sehingga berat jenis semen yang dipadatkan mendekati berat jenis magnesium oksida (MgO) standar, angkat cincin perlahanlahan dengan semen yang dipadatkan berada di bagian dalam. Siapkan sebanyak 3 benda uji untuk pengukuran derajat warna putih, lalu membaca derajat warna yang tertera pada display. 


\section{Hasil dan Pembahasan}

Penelitian ini melakukan uji sifat kimia dan fisika terhadap bahan baku semen portland putih dan produk portland semen putih. Uji yang dilakukan pada bahan baku adalah uji LOI, sedangkan uji produk meliputi uji LOI, uji $\mathrm{SO}_{3}$, dan uji warna. Pengujian kehilangan berat akibat pembakaran (LOI) dilakukan pada semen untuk menentukan kehilangan berat jika semen dibakar sampai sekitar $(900-1000){ }^{\circ} \mathrm{C}$. Hasil uji bahan baku Semen Portland Putih tertera pada Tabel 3.

Tabel 3. Hasil uji LOI Bahan Baku Semen Portland Putih

\begin{tabular}{cccc}
\hline Bahan & Sampel 1 & Sampel 2 & Sampel 3 \\
\hline Terak & $89 \%$ & $88 \%$ & $88 \%$ \\
Gypsum & $7 \%$ & $8 \%$ & $7 \%$ \\
Batu Kapur & $4 \%$ & $4 \%$ & $5 \%$ \\
\hline
\end{tabular}

LOI menyatakan bagian dari zat yang akan terbebaskan sebagai gas pada saat terpanaskan atau dibakar (temperatur tinggi). Metode LOI dipakai untuk memperkirakan bahan organik dan kandungan karbon pada sedimen [9]. Pada bahan baku umpan kiln semakin tinggi LOI-nya, maka semakin sedikit umpan kiln yang menjadi produk clinker. Oleh karena itu LOI yang tinggi mengurangi efisiensi proses karena adanya mineral-mineral yang dapat diuraikan pada saat pembakaran. Komponen utama LOI adalah uap air yang berasal dari kandungan air (moisture) dalam bahan baku (raw mix) dan gas $\mathrm{CO}_{2}$ yang akan dihasilkan dari proses kalsinasi $\mathrm{CaCO}_{3}$. Hasil uji bahan baku menyatakan bahwa LOI terendah diperoleh pada sampel 2 dan 3 (untuk terak), sampel 1 dan 3 (untuk gypsum) serta sampel 1 dan 2 (untuk batu kapur). Hasil uji LOI produk semen portland putih disajikan pada Tabel 4 . Hasil uji LOI rata-rata 10 sampel semen portland dari 10 pabrik semen di Indonesia adalah sebesar 5,75\% [10]. Uji hasil sampel semen porland putih penelitian ini tertera pada Tabel 4.

Tabel 4. Hasil Uji Kimia LOI pada Semen Portland Putih

\begin{tabular}{cccc}
\hline Uji & Sampel 1 & Sampel 2 & Sampel 3 \\
\hline LOI & $4,96 \%$ & $5,22 \%$ & $5,31 \%$
\end{tabular}

Nilai LOI yang paling tinggi adalah pada sampel 3 dengan nilai LOI sebesar $5,31 \%$ dan nilai LOI paling rendah adalah pada sampel 1 dengan nilai LOI sebesar 4,96\%. Nilai LOI sesuai dengan Standar Nasional Indonesia (SNI) adalah maksimal 5,0\% [8], demikian pula Standar Eropa EN 1971:2000 [3]. Sampel yang memenuhi nilai LOI sesuai Standar Nasional Indonesia (SNI) adalah sampel 1.

Kandungan $\mathrm{SO}_{3}$ dalam semen adalah untuk mengatur atau memperbaiki sifat setting time (pengikatan) dari mortar (sebagai retarder) dan juga untuk kuat tekan. Pemberian retarder terlalu banyak akan menimbulkan kerugian pada sifat expansive dan dapat menurunkan kekuatan tekan. Sebagai sumber utama $\mathrm{SO}_{3}$ yang sering banyak digunakan adalah gypsum. Hasil Uji Kimia $\mathrm{SO}_{3}$ pada Semen Portland Putih tertera pada Tabel 5.

Tabel 5. Hasil Uji Kimia $\mathrm{SO}_{3}$ pada Semen Portland Putih

\begin{tabular}{cccc}
\hline Kandungan & Sampel 1 & Sampel 2 & Sampel 3 \\
\hline $\mathrm{SO}_{3}$ & $1,8 \%$ & $3,53 \%$ & $2,8 \%$ \\
\hline
\end{tabular}

Hasil uji $\mathrm{SO}_{3}$ rata-rata semen portland produksi 10 pabrik semen di Indonesia sebesar $2,12 \%$ [10]. Sesuai hasil uji yang tertulis di tabel 5, sampel yang memenuhi Standar Nasional Indonesia yaitu sampel 1, sedangkan untuk sampel 2 dan sampel 3 didapatkan nilai yang melebihi maksimal dari Standar Nasional Indonesia (SNI 15-2049-1994).

Pengujian warna dilakukan dengan alat Kett Meter. Hasil uji warna Semen Portland Putih tertera pada tabel 6.

Tabel 6. Hasil Uji Fisika (Warna) pada Semen Portland Putih

\begin{tabular}{cccc}
\hline Uji & Sampel 1 & Sampel 2 & Sampel 3 \\
\hline Warna & $93,4 \%$ & $93,3 \%$ & $93,3 \%$
\end{tabular}

Hasil uji warna portland warna semen putih menyatakan bahwa semua sampel mempunyai nilai di atas 90. Standar Nasional Indonesia (SNI 15-2049-1994) menyatakan derajat warna putih semen portland putih dengan alat kett meter adalah minimal 80. Dengan demikian semua sampel 
memenuhi Standar Nasional Indonesia untuk syarat fisika berupa warna. Sedangkan sampel yang memenuhi semua standar yang diuji, yaitu standar LOI, kadar $\mathrm{SO}_{3}$ dan uji warna adalah sampel 1 dengan komposisi $89 \%$ terak, $7 \%$ gypsum, dan $4 \%$ batu kapur:

\section{Kesimpulan}

Semen portland putih adalah semen hidrolisis yang berwarna putih dan dihasilkan dengan cara menggiling terak semen portland putih yang terutama terdiri atas kalsium dan silikat, digiling bersama-sama dengan bahan tambahan berupa satu atau lebih bentuk kristal senyawa kalsium sulfat. Semen portland putih merupakan bahan dekoratif yang memerlukan kualitas memenuhi persyaratan Standar Nasional Indonesia. Komposisi yang baik untuk gypsum, batu kapur, dan terak putih dalam pembuatan semen putih adalah komposisi pada sampel 1, yaitu gypsum 7\%, batu kapur 4\%, dan terak putih $89 \%$. Semua hasil uji dari sampel 1 memenuhi Standar Nasional Indonesia (SNI 152049-1994) berupa uji LOI, uji $\mathrm{SO}_{3}$, dan uji warna.

\section{Ucapan Terima Kasih}

Peneliti mengucapkan terima kasih kepada Department of Quality Control, PT Semen Indonesia, Gresik yang telah menyediakan bahan dan fasilitas untuk penelitian ini.

\section{Daftar Pustaka}

[1] C. Argiz, M. Ángel Sanjuán, and E. Menéndez, "Coal bottom ash for portland cement production", Advances in Materials Science and Engineering, vol. 2017, pp. 1-7, 2017.

[2] J. Liu , W. Li , F. Zhang, X. Zhang, L. Chen, and Y. Liu, "Optimization and hydration mechanism of composite cementing material for paste filling in coal mine", Advances in Materials Science and Engineering, vol. 2019, pp. 1-13, 2019.

[3] A. L. Mrema, "Comparison of the properties of Portland cement and Portland-limestone cement", Conference: Advances and Trends in Structural Engineering, Mechanics and Computation (SEMC 2010), Cape Town, September 2010.

[4] W. L. Greer, A. J. Buonicore and W. T. Davis, "Portland Cement", Air Pollution Engineering Manual, (eds.), Von Nostrand Reinhold, NY, 1992.

[5] Portland Cement Association, "U.S. And Canadian Portland Cement Industry Plant Information Summary", Washington DC, August 1991.

[6] W.H. Duda, "Cement Data Book Raw Material for Cement Production”, $1^{\text {st }}$ ed, Berlin. 1988.

[7] IS 8042: 1989 amendment no. 5 April 2009, Indian Standard: White Portland specification, 2nd revision, Bureau of Indian Standards, New Delhi.

[8] SNI 15-0129-2004, Semen portland putih, Badan Standardisasi Nasional.

[9] O. Heiri, A. F. Lotter, G. Lemcke, "Loss on ignition as a method for estimating organic and carbonate content in sediments: reproducibility and comparability of results", Journal of Paleolimnology, Vol. 25, pp. 101-110, 2001.

[10]R. R. Irawan, "Kajian sifat kimia, fisika, dan mekanik semen portland di indonesia", Jurnal JalanJembatan, Vol. 34 No. 2, pp 79-90, Juli-Desember 2017. 